\title{
COMPARATIVE STUDY AND EMPIRICAL MODELLING OF PULVERIZED COCONUT SHELL, PERIWINKLE SHELL AND PALM KERNEL SHELL AS A POZZOLANS IN CONCRETE
}

\author{
Efe Ewaen Ikponmwosa, Samuel Onosedeba Ehikhuenmen*, \\ KARIEREN KATE IRENE
}

\author{
University of Lagos, Faculty of Engineering, Department of Civil and Environmental Engineering, Sapara Road, \\ 100213, Akoka, Lagos, Nigeria \\ * corresponding author: sehikhuenmen@unilag.edu.ng
}

\begin{abstract}
Infrastructural development across the world is fast growing due to the rapid growth in population. This has resulted in consequently creating an increase in the demand for construction materials, especially cement. This study presents a report of a concise investigation on the pozzolanic potentials of Pulverized Coconut Shell (PCS), Periwinkle Shell (PPS) and Palm Kernel Shell (PPKS). The chemical composition of the PCS, PPS and PPKS, physical properties of concrete constituents and mechanical properties of the pozzolans blended concrete were determined. A concrete mix ratio of $1: 2: 4$ with a w/c of 0.6 was adopted. A total of 270 cubes and 120 cylinders were cast at an interval of $10 \%$ from $0 \%$ to $50 \%$ replacement level and cured in water for 7, 14, 21 and 28 days. Results indicate that the PCS, PPS and PPKS are good retarders as they increased the setting time of cement paste and decreased the workability of concrete as the percentage replacement increased. The addition of the PCS in the mix produced a concrete of lower density while the addition of the PPS and PPKS produced a concrete of a higher density up to a $30 \%$ replacement level, further increase resulted to a decrease in density. The compressive and tensile strengths increased with a curing age but decreased with an increasing percentage replacement level for the three pozzolans investigated. However, $10 \%$ replacement level of the PCS, PPS and PPKS in concrete is suitable for the production of pozzolans blended concrete for structural works. The models developed are in a good agreement with the experimental results.
\end{abstract}

KEYwORDs: Pulverized coconut shell (PCS), pulverized periwinkle shell (PPS), pulverized palm kernel shell (PPKS), structural strengths, empirical models.

\section{INTRODUCTION}

Infrastructural development across the world is fast rising, and this is consequently creating an increase in the demand for construction materials. Concrete is listed among the most extensively used construction materials worldwide and its production is daily on the increase to service the demand for the infrastructure development. Cement, which is the main binder in the production of concrete is very expensive; particularly in developing countries [1]. Besides its high cost, its production is associated with very high temperatures with an attendant emission of poisonous gases, such as $\mathrm{CO}_{2}, \mathrm{NO}, \mathrm{NO}_{2}$, as well as depletion of natural resources such as limestone [2]. More so, due to increasing industrial and agricultural activities, tonnes of waste materials like as steel slag, palm kernel, rice husk, saw dust, groundnut husk, periwinkle shell, coconut shell, etc, are deposited in the environment without littleany effective method of waste management and recycling [3]. Some of these deposits are not easily decomposed and the accumulation has constituted to various forms of environmental challenges, hence there is a need to reuse them in order to minimize their negative effects on the environment.
The American society of testing materials (ASTM) [4] defines Pozzolans as siliceous or aluminous materials, which possess little or no cementitious properties but will, in finely divided form and in the presence of moisture, react with lime $\left[\mathrm{Ca}(\mathrm{OH})_{2}\right]$ at ordinary temperature to form a compound having cementitious properties [5]. Many achievements have been made regarding to pozzolanic materials and the subject is still attracting much research due to its functional benefit of waste reusability and sustainable development, its indigenous technology and equipment requirements, and reduction in construction costs are added advantages.

Some findings of waste materials reveal a great significant effect on its mechanical properties of pozzolan blended concrete. Golewski [6], investigated the effect of the addition of siliceous fly ashes (FA) in the amount of 0,20 and $30 \%$ by weight of cement on the interfacial microcracks and mechanical parameters in plain concrete. He discovered that the using the $20 \%$ FA cement binder could trigger favourable changes in the microstructure of concrete leading to an improvement in its mechanical properties. Also, the addition of fly ash into the concrete matrix up to $20 \%$ resulted to a marginal increase of the fracture 
toughness of plain concrete, while $30 \%$ FA additive led to a significant decrease [7, 8].

Falade et al. 9, examined the Potential of Pulverized Bone as a pozzolanic material. Results of an investigation revealed no substantial difference in strength propertiesy of specimens having pulverised bone up to $20 \%$ replacement at 28 days curing age when compared to the control specimens. From the results of the study, it was concluded that pulverised bone had pozzolanic properties and could be used to replace cement partially. Ikponmwosa et al. [10, investigated the Strength Characteristics of Concrete Beams with Cement Partially Replaced by Uncalcined Soldier-Ant Mound Clay. Results indicated that the addition of SAMC in the mix produced a concrete of a lower density than normal concrete; increased the setting times of cement with increased workability. The density as well as the flexural strength of concrete decreased with increase in SAMC content. However, $5 \%$ SAMC content in the mix was considered as optimalum for an improved structural performance when compared with normal concrete. Ikponmwosa et al. [11, presented a study on the suitability of polyvinyl waste powder as a partial replacement for cement in concrete production. As part of their findings, polyvinyl waste powder has a pozzolanic effect, served as a retarder, reduced workability and higher structural strength up to a $20 \%$ replacement. Reddy et al. 12, studied the utilization of sugarcane bagasse ash in concrete by a partial replacement of cement. The results showed that the performance of concrete having up to a $10 \%$ SCBA replacement met the requirements of BS 8110 [13] and can be used for the production of concrete for structural works. Marthong [14, researched on the usage of sawdust ash (SDA) as a part replacement of cement in concrete production. The test results disclosed that the addition of SDA triggered only a little expansion due to a little calcium content. Early strength growth was observed to be around 50-60\% of their 28 days strength. It was recommended that the usage of SDA as a part replacement of cement should not exceed $10 \%$ by volume in all grades of cement.

Utsev \& Taku [15], studied the application of coconut shell ash as a replacement of ordinary portland cement in concrete production. The results revealed that the densities of concrete cubes for a $10-15 \%$ replacement was were above $2400 \mathrm{~kg} / \mathrm{m}^{3}$ and the compressive strength increased from $12.45 \mathrm{~N} / \mathrm{mm}^{2}$ at 7 days to $31.78 \mathrm{~N} / \mathrm{mm}^{2}$ at 28 days curing; thus, meeting the requirement for the use in both heavy weight and light weight concreting. In conclusion, the study revealed that a 10 to $15 \%$ partial replacement of the OPC with the CSA using a $\mathrm{W} / \mathrm{C}$ ratio of 0.5 was suitable for a production of both heavy weight and light weight concrete. Umoh \& Femi [16] investigated the behaviour of ternary blended cement concrete integrating periwinkle shell ash (PSA) and bamboo leaf ash (BLA) as cement enhancers. The result revealed that at 28- and 56-days hydration, ternary blended cement concrete containing a combined percentage of PSA and BLA of $20 \%$ cement replacement attained high compressive and tensile strength and low water absorption. Hence, from the result, it was concluded that blended cement concrete with a $20 \%$ replacement of cement with the PSA and BLA was considered optimum for ternary blended cement concrete.

Offiong \& Akpan [17] discovered, in the assessment of physico-chemical properties of periwinkle shell ash as part replacement for cement in concrete production, that Periwinkle shell ash calcined at $800^{\circ} \mathrm{C}$ met the required maximum $34 \%$ as stipulated by ASTMC618 [18] is appropriate for the usage as a part replacement for cement in concrete production. As the percentage replacement level of PSA content increases, the strength properties of concrete reduces and the increase in curing age led to an increased strength for specimens cured in water (control); while for the specimen cured in sulphuric acid solutions, the strength properties decreased with age [19]. Similar findings were observed by Abdullahi and Sara [20] and Olutoge et al. 21.

Olutoge et al. 22] examined the strength properties of palm kernel shell ash concrete. From their research findings, the compressive strength for the PKSA blended concrete was lower than for a normal concrete but at a $10 \%$ replacement, its 28 -day strength of been $22.8 \mathrm{~N} / \mathrm{mm}^{2}$ is within the recommended strength for reinforced concrete. The combination of palm kernel shell ash with other Supplementary Cementitious Materials (SCM) had been researched and found to improve the strength properties of concrete [23, 24].

Utsev and Taku [15] investigated coconut shell ash as a partial replacement of ordinary Portland cement in concrete production. They discovered that the density of concrete increases with the increase in the CSA contents but the compressive strength decreases as the replacement level of CSA increases. It was concluded that a $10 \%$ replacement level is optimal for replacing cement with the CSA. The decline in strength can be attributed to the nature of the CSA acting more as a filler material than a binding material $[25]$. Oyedepo et al. 26] carried out a study on the performance of coconut shell ash and palm kernel shell ash as partial replacement for cement in concrete. The results revealed that a $20 \%$ PKSA and CSA replacement in cement gave an average optimum compressive strength of $15.4 \mathrm{~N} / \mathrm{mm}^{2}$ and $17.26 \mathrm{~N} / \mathrm{mm}^{2}$, respectively, at 28 days. It was concluded that the optimum replacement level of a $10 \%$ replacement is suitable for both light weight and heavy weight concrete production. Akhionbare [27] evaluated the usage of agro-waste as a partial replacements for cement in construction production. The seven selected agro-wastes are wood ash (WA), bone powder ash (BPA), acha husk ash (AHA), bambara ground shell ash (BGSA), rice husk ash (RHA), palm oil shell ash (POSA) and groundnut husk ash (GHA). The chemical analysis of the ash 
for each material was done with the Bogue's model. A linear program calculates the equations governing the model for an ease of complex computations. The results revealed that bone ash (BA) has the highest compressive strength and C3S composition while rice husk is the most economically viable.

Global pollution coupled with resource depletion has inspired several engineers and researchers to search for these locally available resources with a view goal to investigateing their usefulness either wholly as a construction material or partly as a substitute for conventional ones in concrete production. The search revealed that Coconut Shell Ash, Periwinkle Shell Ash and Palm Kernel Shell Ash haves been used as a partial replacement of cement. However, little or no literature exists on the use of these three materials in their natural state (in pulverized form). Thus, this paper presents the comparative study between the characterization of pulverized coconut shell, periwinkle shell and palm kernel shell as pozzolans in concrete. This research is aimed at reducing the cost of concrete production and $\mathrm{CO}_{2}$ emission by incorporating pozzolan (biodegradable waste) without compromising the concrete strength. Also, its serves as an encouragement for a low-cost housing scheme for real estate investors and developers.

\section{MAterials \& Methods}

\subsection{MATERIALS}

The cement used in this study was ordinary Portland cement (OPC), which conforms to the requirements set under ASTM C-150 [28], BS 12 [29] and BS EN 197-1 [30]. The pulverized coconut shell, periwinkle shell and palm kernel shell were gotten from matured shells at Badagry (Lagos state), Bariga (Lagos state) and Abeokuta (Ogun state), respectively. The shells were washed to remove impurities and sun-dried for 48 hours after which they were broken into small pieces and fed into a pulveriser. The powder from the pulveriser was then sieved using the sieve size with $90 \mu \mathrm{m}$ micron size. The shaft retained on the sieve was then collected and taken back to the pulveriser for a further processing.

Coarse aggregates were crushed granite ranging from $12.5 \mathrm{~mm}$ to $19 \mathrm{~mm}$ sizesin size, obtained from a quarry located in Ogun state. The fine aggregate used was river sand gotten from River Ogun, which was free from organic matter and salt. The gradation test as presented in Table 3 showed that they met specifications requirements in accordance to BS 882 [31. The water used for this research was clean, portable and impurities-free obtained from University of Lagos Water Distribution System, which was in an accordance with BS 3148 [32.

\subsection{Methodology}

\subsubsection{MiX DESIGN AND SAMPLE PREPARATION}

The design mix proportions for Grade 30 concrete were $310.85 \mathrm{Kg} / \mathrm{m}^{3}, 621.70 \mathrm{Kg} / \mathrm{m}^{3}, 1243.40 \mathrm{Kg} / \mathrm{m}^{3}$ and $186.51 \mathrm{Kg} / \mathrm{m}^{3}$ for cement, sand, granite and water respectively, with a $\mathrm{W} / \mathrm{C}$ ratio of 0.60 for one cubic meter of concrete. A total of 270 Nos. $150 \mathrm{~mm} \times 150 \mathrm{~mm}$ $\times 150 \mathrm{~mm}$ concrete cubes and 120 Nos. $150 \mathrm{~mm} \times$ $300 \mathrm{~mm}$ concrete cylinder specimens were cast, cured and tested. 90 cubes and 40 cylinders were cast using each of the materials at different replacement levels from $0 \%$ to $50 \%$ at $10 \%$ intervals for pulverized coconut shell, periwinkle shell and palm kernel shell respectively. A concrete mixer was used for mixing the concrete constituents to produce freshly mixed concrete. The mixtures were poured into various moulds for different concrete elements and compacted using tapping rod and vibrating machine. The specimens were demoulded after $24 \pm 2$ hours and cured in potable water.

The specimens were de-moulded $24 \pm 2$ hours after the casting and stored in the curing medium until the age of the test of $7,14,21$ and 28 days for the cubes and cylinders.

\subsubsection{TESTING PROCEDURE}

A Cchemical analysis was carried out on the PCS, PPS and PPKS in the Department of Chemistry, University of Lagos. Setting time test was conducted on the cement paste replacement with the PCS, PPS and PPKS. Also, workability was determined in the fresh state of the concrete having the PCS, PPS and PPKS using a slump test.

Compressive strength test was conducted using Avery Dension Universal Testing Machine having a loading rate of $120 \mathrm{kN} / \mathrm{min}$, which was is in an accordance with BS EN 12390-3 33]. The Ssplitting tensile strength test was done in an accordance with BS EN 12390-6 34] and ASTM C496-96 35] using a loading rate of $120 \mathrm{kN} / \mathrm{min}$.

\subsubsection{MATHEMATICAL MODEL}

The results of and the experimental data for various properties of pozzolan blended concrete were analysed using a bilinear interpolation method to develop mathematical models for predicting parameters with respect to its variables. The algorithm for the bilinear interpolation method for the value of the unknown function $f$ at points $x$ and $y$. For a known value of $f$ at four points; $Q_{11}=\left(x_{1}, y_{1}\right), Q_{12}=\left(x_{1}, y_{2}\right)$, $Q_{21}=\left(x_{2}, y_{1}\right), Q_{22}=\left(x_{2}, y_{2}\right)$. Linear interpolation in the $\mathrm{x}$-direction, we have:

$$
\begin{aligned}
& f_{x, y_{1}}=\frac{x_{2}-x}{x_{2}-x_{1}} f\left(Q_{11}\right)+\frac{x-x_{1}}{x_{2}-x_{1}} f\left(Q_{21}\right) \\
& f_{x, y_{2}}=\frac{x_{2}-x}{x_{2}-x_{1}} f\left(Q_{12}\right)+\frac{x-x_{1}}{x_{2}-x_{1}} f\left(Q_{22}\right)
\end{aligned}
$$




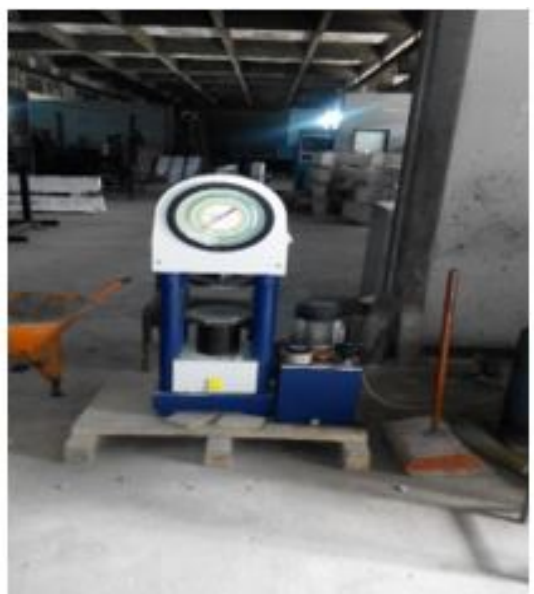

(A).

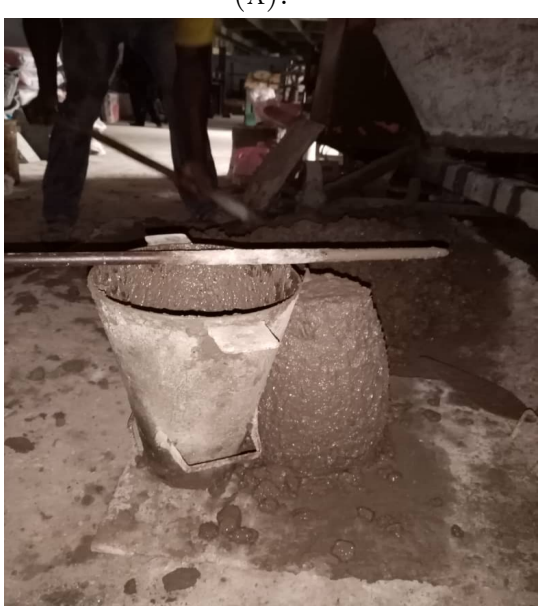

(D).

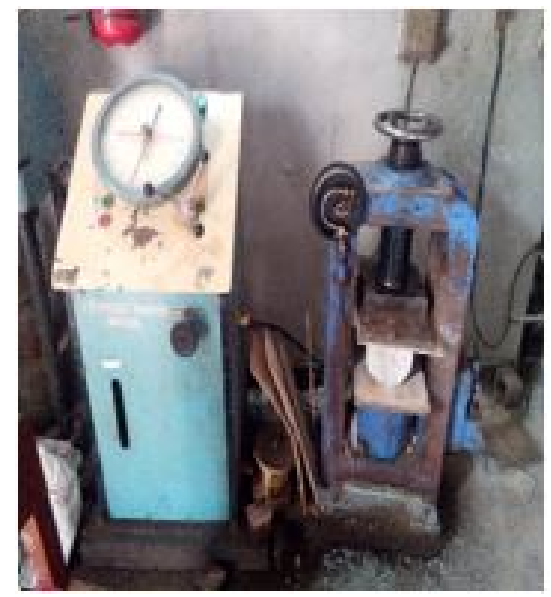

(в).

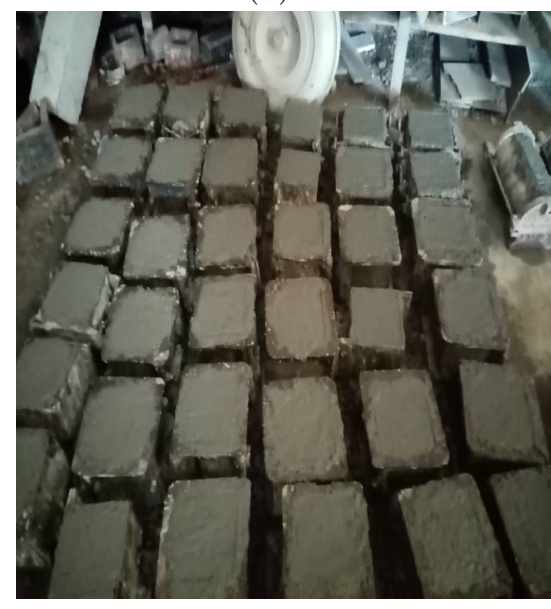

$(\mathrm{E})$.

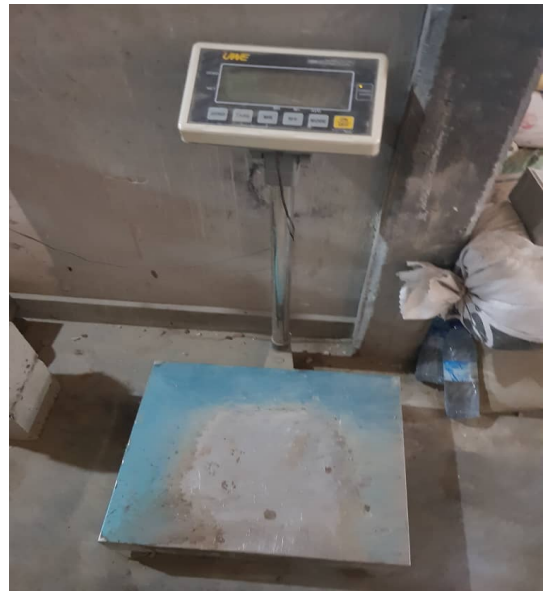

(C).

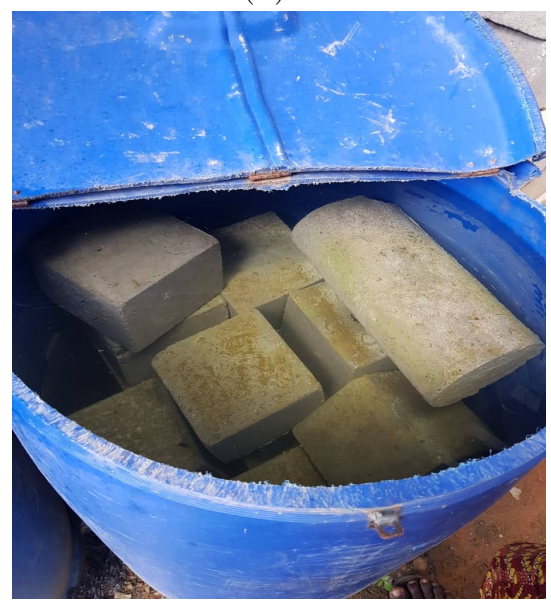

(F).

Figure 1. Laboratory Equipment and Experimental Activities (a, b) Avery Dension Universal Testing Machine (c) Material Measurement using Weighing Machine (d) Slump Test (e) Casting of Concrete Cubes (f) Concrete Cubes Immersed in Potable Water Curing.

Interpolating in the $\mathrm{y}$-direction to obtain the desired estimate:

$$
f_{x, y}=\frac{y_{2}-y}{y_{2}-y_{1}} f\left(x, y_{1}\right)+\frac{y-y_{1}}{y_{2}-y_{1}} f\left(x, y_{2}\right)
$$

Comparisons of the predicted results obtained from the use of the bilinear interpolation method was made with the observed experimental results at unique check points using a simple percentage difference formula;

$$
\text { Per.Diff. }=\frac{\text { actual result }- \text { model result }}{\text { actual result }} \cdot 100 \% \text {. }
$$

\section{Results AND Discussion}

\subsection{Chemical analysis of PUlverized COCONUT SHELL, PERIWINKLE SHELL AND PALM KERNEL}

The chemical analysis of the PCS, PPS and PPKS was carried out and the chemical compositions determined. The results are shown in Table 1

The physical observation shows that the samples are different in colour (brown) when compared to cement (light grey), which does not translate to the ability to perform alike, but their individual performance is based on the degree of constituents' chemical elements present in them. It was observed that the combined percentage masses of silica $\left(\mathrm{SiO}_{2}\right)$, alumina $\left(\mathrm{Al}_{2} \mathrm{O}_{3}\right)$ and ferric oxides $\left(\mathrm{Fe}_{2} \mathrm{O}_{3}\right)$ for the samples were lower than the various class type of pozzolans according to ASTM C618-12a [36]. CaO, known for providing strength in cement, was observed to be very low in the samples.

This can be attributed to the low strength performance and increase in setting time. The absence of $\mathrm{SiO}_{2}$ and $\mathrm{Al}_{2} \mathrm{O}_{3}$ in the samples would have an adverse effect on the strength and setting property of the cement paste binding the aggregates together.

The $\mathrm{MgO}$ was found to be within the lower limit range of less for cement, PPS and PPKS but the PCS sample recorded higher value which can be attributed to the reduction of strength of concrete [28, 36]. The percentages of $\mathrm{Na} 2 \mathrm{O}$ and $\mathrm{K} 2 \mathrm{O}$ known as the alkali oxides in the samples were observed to be large when compared to the standard range [36]. This resulted 


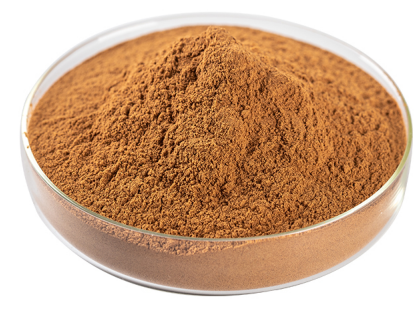

(A).

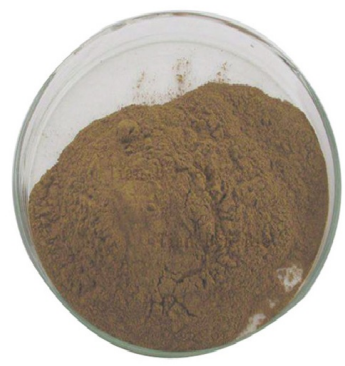

(C).

(B).

Figure 2. Supplementary Cementitious Materials (SCM) (a) Pulverized Coconut Shell (b) Pulverized Palm Kernel Shell (c) Pulverized Periwinkle Shell.

\begin{tabular}{lcccc}
\hline Parameters & Cement & $\begin{array}{c}\text { Pulverized Coconut } \\
\text { Shell }(\%)\end{array}$ & $\begin{array}{c}\text { Pulverized Periwinkle } \\
\text { Shell }(\%)\end{array}$ & $\begin{array}{c}\text { Pulverized Palm } \\
\text { Kernel Shell }(\%)\end{array}$ \\
\hline Calcium Oxide $(\mathrm{CaO})$ & 63.97 & 8.918 & 10.84 & 9.68 \\
Silica $\left(\mathrm{SiO}_{2}\right)$ & 18.34 & 27.57 & 22.32 & 20.28 \\
Aluminium Oxide $\left(\mathrm{Al}_{2} \mathrm{O}_{3}\right)$ & 4.73 & 14.38 & 9.37 & 3.38 \\
Ferric Oxide $\left(\mathrm{Fe}_{2} \mathrm{O}_{3}\right)$ & 0.38 & 5.82 & 6.89 & 7.42 \\
Potassium Oxide $\left(\mathrm{K}_{2} 0\right)$ & 0.48 & 6.981 & 4.98 & 6.81 \\
Magnesium Oxide $(\mathrm{MgO})$ & 2.16 & 3.196 & 2.49 & 2.89 \\
Sodium Oxide $\left(\mathrm{Na}_{2} \mathrm{O}\right)$ & 0.55 & 5.189 & 6.12 & 5.81 \\
Chlorine $(\mathrm{Cl})$ & 1.83 & 6.28 & 7.62 & 6.58 \\
Sulphate $\left(\mathrm{SO}_{4}^{2-}\right)$ & 0.51 & 8.00 & 7.40 & 7.60 \\
\hline
\end{tabular}

TABLE 1. Chemical Composition of Supplementary Cementitious Materials (SCM) and Cement.

in some difficulties in regulating the setting time of the cement paste.

\subsection{Physical PROperties AND SIEVE ANALYSIS}

Results of the physical properties tests on the concrete constituent used in this study are presented in Table2.

According to Unified soil classification system [37, 38 , the coarse aggregate is classified as poorly graded granite because its coefficient of uniformity $\left(C_{u}=\right.$ $\left.D_{60} / D_{10}\right)$ value is less than 4 and Coefficient of Curvature $\left(C_{c}=\left(D_{30} \times D_{30}\right) /\left(D_{60} \times D_{10}\right)\right)$ value is between 1-3 as presented in Figure 3 . Also, the fine aggregate is classified as poorly graded sand because its $C_{u}$ value is less than 6 and its $C_{c}$ value is between 1-3 [37, 38].

The densities and specific gravity of the concrete constituents used met the specified standards of Specific Gravity (2.4-2.9), Bulk Density for the aggregates are classified as normal weight aggregate according American Standard Test Method [39. The aggregate crushing and impact values of 22.01 and 13.26 respectively were in an accordance with the relevant standards 40.

\subsection{EFFECT OF POZZOLANS ON THE SETTING TIMES OF CEMENT}

The results of the setting time tests of cement paste having pozzolans incorporated at various replacement levels are presented in the figures below.

It was observed that the initial setting times of cement and pozzolans are higher than the specified standard of 45 minutes but their final setting time recorded a lower time, which is within the specified standard of 600 minutes [41. From figures $4 \mathrm{a}$ and $4 \mathrm{~b}$ it was observed that both the initial and final setting times of the paste incorporated with pozzolans increased as the replacement level of the pozzolans increased.

Specifically, the addition of each of the three materials to cement paste respectively caused a retardation of the setting time. The blended cement with pulverized coconut shell (PSC) had the highest initial and final setting times when compared to others. In order words, these pozzolans are acting as a retarder and could be considered good for temperate regions, or in ready- mix concrete transported over a long distance. This behaviour may be attributed to the reduction of the strength forming compounds (C3S and C3A) in the blended cement through the partial replacement of cement with pozzolans. These compounds are re- 


\begin{tabular}{lcccccc}
\hline Parameters & Granite & Sand & Cement & PCS & PPS & PPKS \\
\hline Coefficient of uniformity $\left(C_{u}\right)$ & 1.58 & 3.03 & - & - & - & - \\
Coefficient of Curvature $\left(C_{c}\right)$ & 1.03 & 1.08 & - & - & - & - \\
Fineness modulus & 3.88 & 4.49 & 4.25 & & & \\
Dry Density $\left(\mathrm{kg} / \mathrm{m}^{3}\right)$ & 1403.29 & 1405.01 & - & - & - & - \\
Bulk Density $\left(\mathrm{kg} / \mathrm{m}^{3}\right)$ & 1407.36 & 1409.55 & 1297 & 1312 & 1320 & 1384 \\
Specific Gravity & 2.66 & 2.63 & 2.75 & 2.40 & 2.46 & 2.64 \\
Moisture Content $(\%)$ & 0.29 & 0.6 & - & 1.45 & 1.23 & 1.34 \\
Aggregate Crushing Value (\%) & 22.01 & - & - & - & - & - \\
Aggregate Impact Value (\%) & 13.26 & - & - & - & - & - \\
\hline
\end{tabular}

Table 2. Physical Properties of Concrete Constituents.

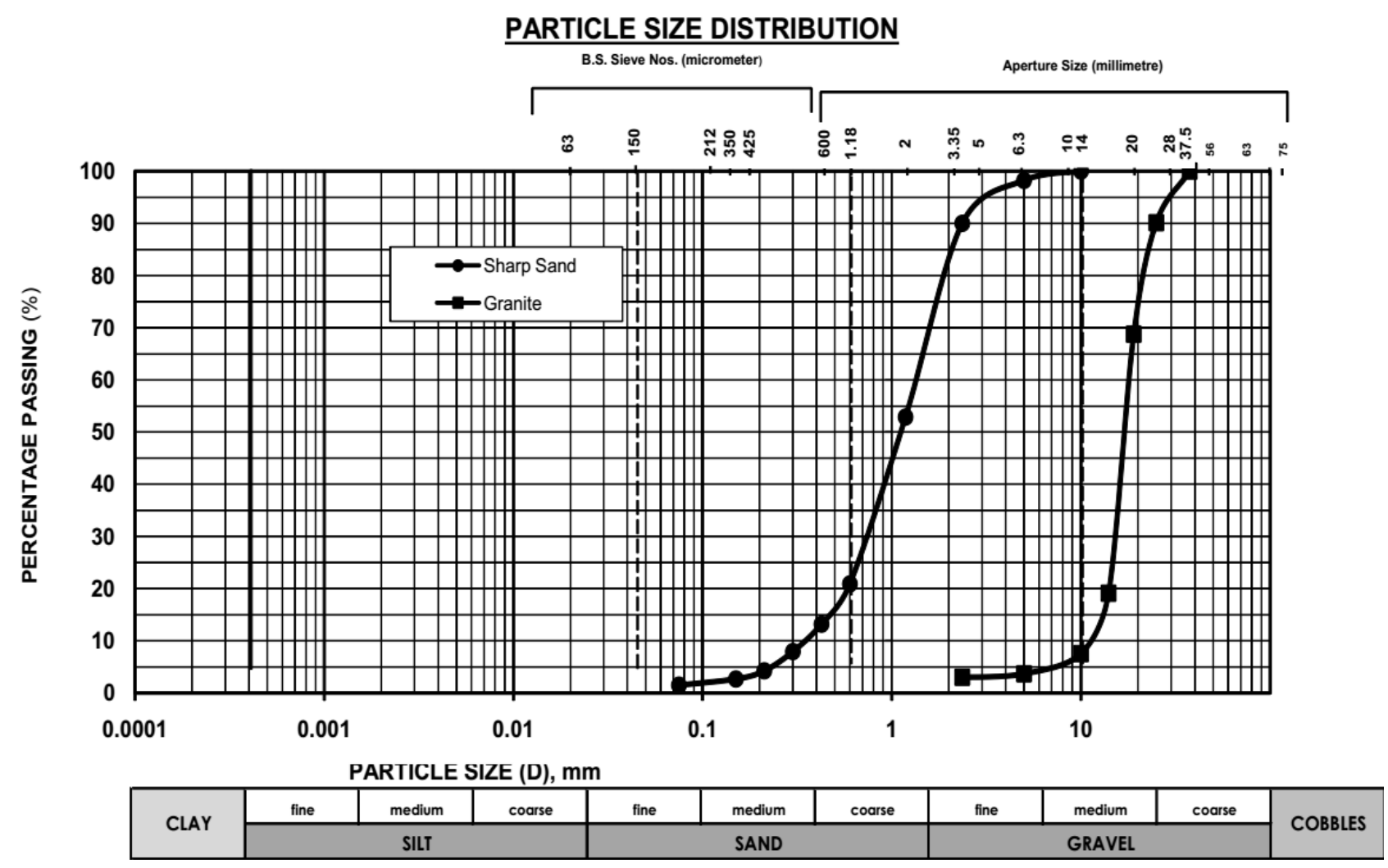

Figure 3. Particle Size Distribution for Aggregates.

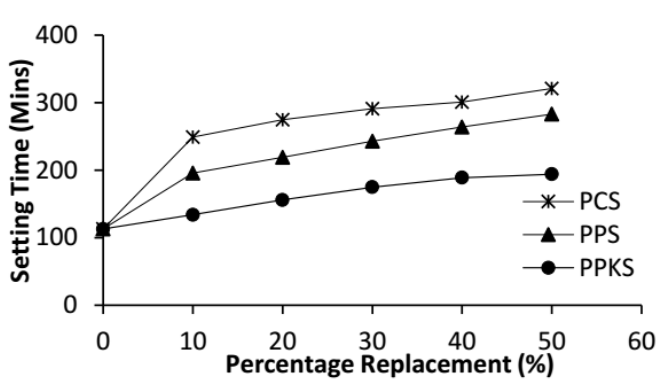

A. Initial Setting Time

(A).

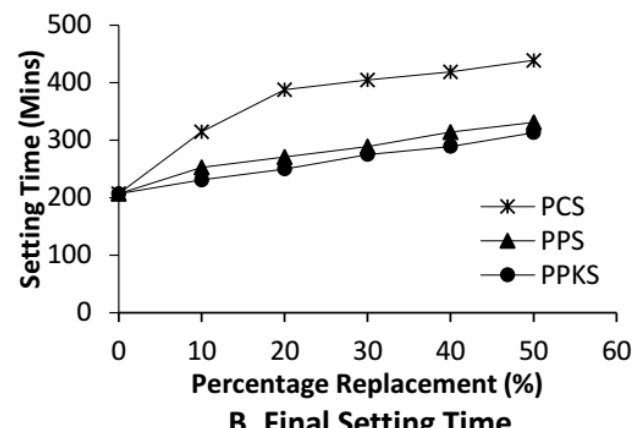

B. Final Setting Time

(в).

Figure 4. Effect of Pozzolans on the Setting Time of Cement Paste. 
sponsible for the early strength gain and the initial and final setting times of cement.

\subsection{EFFECT OF PCS, PPS AND PPKS ON THE WORKABILITY OF CONCRETE}

The variations in the workability of pozzolan blended concrete were determined using slump test and the results revealed a high degree of workability for the PPS and PPKS from control to a $20 \%$ replacement level while the PCS exhibit a high workability for control and at a $10 \%$ replacement level. A further increase in replacement levels for the PCS, PPS and PPKS resulted to a low degree of workability.

Figure 5 shows the variations of the slump value of the PCS, PPS and PPKS blended concretes. The values were taken at different replacement levels. As depicted in the figure, the workability decreased as the replacement level of different pozzolans increased. The trends observed in the slump values can be attributed to the high moisture absorption capacity of the pozzolan particles in the mix as the percentage replacement increased, thus transiting from plastic mix to stiff-plastic mix. Pulverized palm kernel shell was observed to have higher slump values when compared to the other pozzolans.

\subsection{EFFECTs of PCS, PPS AND PPKS ON THE DENSITY OF CONCRETE}

The density of the concretes produced with different pozzolans incorporated into the concrete matrix generally increased as the curing age increased. This could be attributed to the adequate amount of moisture available for continuous hydration and volume stability.

Figure 6a shows the variation of the percentage replacement of three pozzolans (PCS, PPS \& PPKS) on the density of concrete at 7 days curing age. As depicted in the figure, the density of pulverized coconut shell blended concrete decreased as the replacement level increased while the densities of pulverized periwinkle shell blended concrete and pulverized palm kernel shell blended concrete increased for values up to a $30 \%$ replacement level and further replacement levels led to a decrease. Figure 6b shows the effect of different pozzolans (PCS, PPS \& PPKS) on the density of concrete at 28 days curing age. Similar trends were observed for the 7 days curing age when the increase in the replacement of the PCS led to the decrease in density while the increase in the PPS and PPKS resulted in an increase in the density for values up to a $30 \%$ replacement level and subsequent increase gave a decrease in density.

From these figures, the trends observed can be attributed to the quantity of Magnesia or Magnesium oxide present in the concrete matrix. The decrease in the densities of pulverized coconut shell blended concrete can be ascribed to the high quantity of $3.198 \%$ Magnesia above the specified range of o.1 to $3 \%$ which could impart its hardness. Also, when the quantity of the Magnesia in the concrete matrix becomes more than the allowable, it could result in a decrease in the density of concrete as observed in pulverized periwinkle shell and palm kernel shell blended concretes.

\subsection{EFFECTS OF PCS, PPS AND PPKS ON COMPRESSIVE STRENGTH OF CONCRETE}

The variation in the compressive strength of pozzolan blended concretes at different curing ages are presented in Figure 7. It was observed that the compressive strength increased with an increase in curing age. The reason for such behaviour is that the concrete specimens are exposed to an environment that facilitates continuous hydration with resultant strength gains. Also, the curing condition helped in the prevention of moisture loss needed for the continuous hydration.

Figures $7 \mathrm{a}$ and $7 \mathrm{~b}$ illustrate the outcome of having some pozzolans incorporated in concrete at varied curing age. From the figures, it is observed that the compressive strength gradually decreased as the percentage replacement increased from $0 \%$ to $50 \%$ at $10 \%$ intervals for the three pozzolans. However, pulverized coconut shell is observed to yield the lowest compressive strength as its replacement level increased while pulverized periwinkle shell recorded the highest values of compressive strength when compared to the other two pozzolans. The decline in the compressive strength for the three pozzolans can be attributed to the lack of adhesion between the pozzolans and cement paste leading to losses in stability and surface area. Also, the breakdown of the internal structure in the bond strength between the cement-pozzolans paste and aggregates resulted in reduced compressive strength. The compressive strength at 28 days curing age decreased by $13.38 \%, 10.50 \%$ and $16.50 \%$ at $10 \%$ replacement level, $23.98 \%, 16.88 \%$ and $23.93 \%$ at $20 \%$ replacement level, $36.21 \%, 27.53 \%$ and $32.95 \%$ at $30 \%$ replacement level, $45.47 \%, 39.23 \%$ and $45.00 \%$ at $40 \%$ replacement level, $71.27 \%, 52.23 \%$ and $70.07 \%$ at $50 \%$ replacement level for PCS, PPS and PPKS respectively. The values of compressive strength for the three pozzolans are above $17 \mathrm{~N} / \mathrm{mm}^{2}$ at the $10 \%$ replacement level. This indicates that the PCS, PPS and PPKS at $10 \%$ replacement level are suitable for the production of pozzolan blended concretes for structural works using a water-binder ratio of 0.6 .

\subsection{Strength ACtivity index (SAI) ON POZZOLANS BLENDED CONCRETE}

The strength activity index (SAI) measures the pozzolanicity of cement replacement materials (CRMs) and the measure is based on the variation of the strength with respect to its control in percent. According to ASTM [4], a CRM can be classified as a pozzolan if the strength of the blended cement at 7 -day and/or 28-day is not be less than $75 \%$ of the strength of normal concrete. The strength activity 


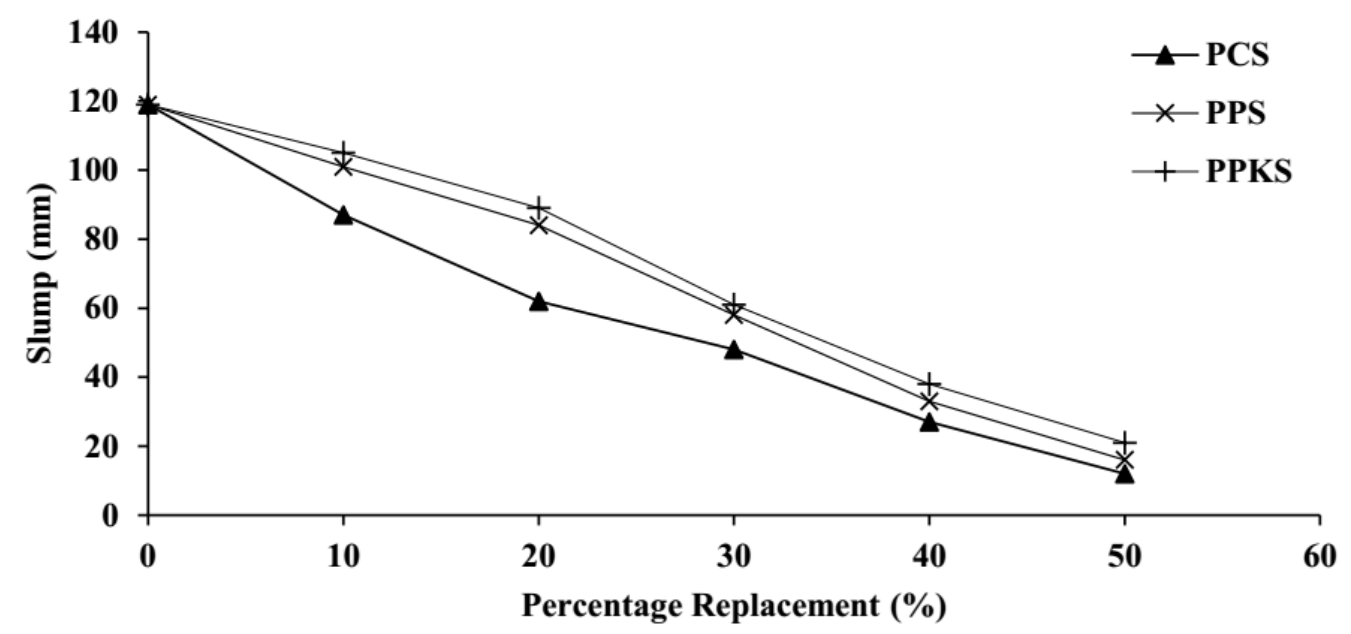

Figure 5. Slump Values of Pozzolans Blended Concrete in Fresh Mix Stage.

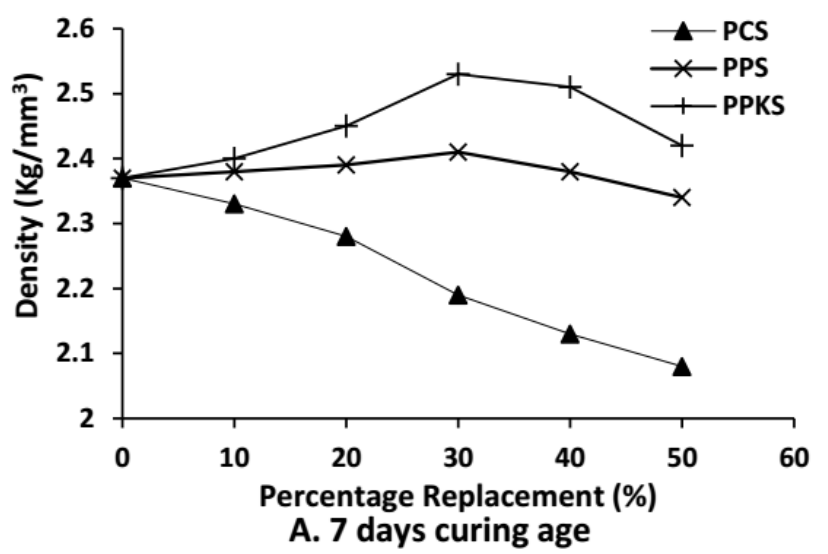

(A).

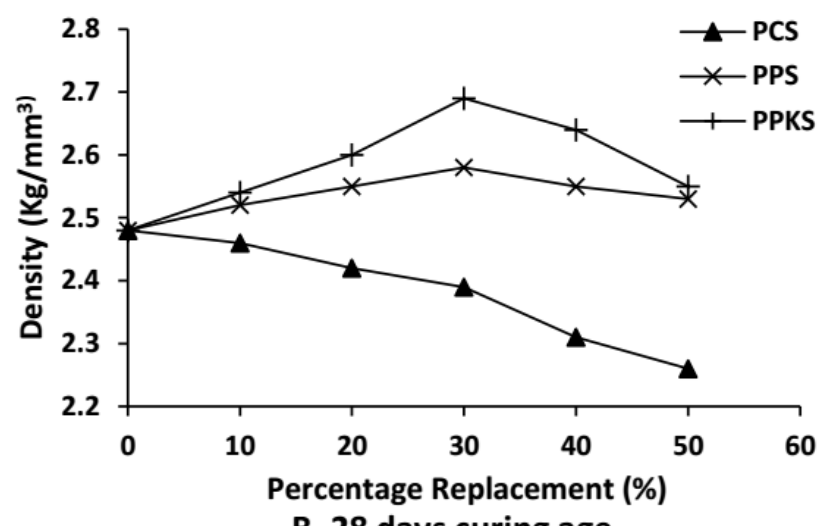

B. 28 days curing age

(B).

Figure 6. Densities of Pozzolans Blended Concrete at 7 days and 28 days Curing Ages.

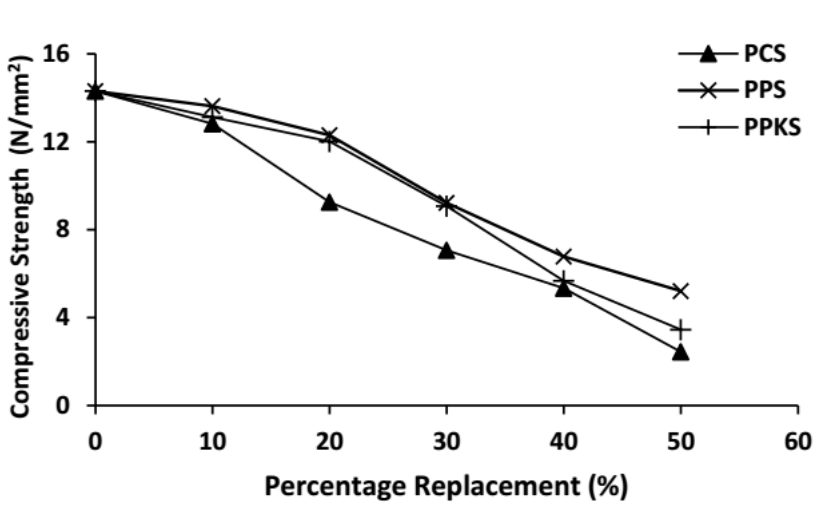

A. 7 days curing age

(A).

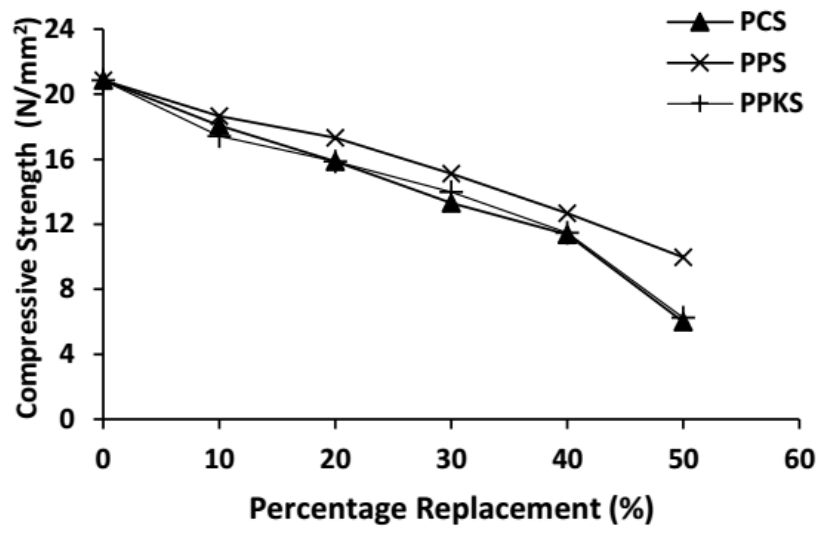

B. 28 days curing age

(B).

Figure 7. Compressive Strength of Pozzolans Blended Concrete at 7 and 28 days curing ages. 


\begin{tabular}{|c|c|c|c|c|c|c|c|}
\hline \multirow{2}{*}{$\begin{array}{l}\text { Curing } \\
\text { Age }\end{array}$} & \multirow{2}{*}{$\begin{array}{c}\text { Percentage } \\
\text { Replacement } \\
(\%)\end{array}$} & \multicolumn{2}{|c|}{ PCS } & \multicolumn{2}{|c|}{ PPS } & \multicolumn{2}{|c|}{ PPKS } \\
\hline & & $\begin{array}{c}\mathrm{CS} \\
\left(\mathrm{N} / \mathrm{mm}^{2}\right)\end{array}$ & $\begin{array}{l}\text { SAI } \\
(\%)\end{array}$ & $\begin{array}{c}\mathrm{CS} \\
\left(\mathrm{N} / \mathrm{mm}^{2}\right)\end{array}$ & $\begin{array}{l}\text { SAI } \\
(\%)\end{array}$ & $\begin{array}{c}\mathrm{CS} \\
\left(\mathrm{N} / \mathrm{mm}^{2}\right)\end{array}$ & $\begin{array}{l}\text { SAI } \\
(\%)\end{array}$ \\
\hline \multirow{6}{*}{7 Days } & 0 & 14.3 & 100 & 14.3 & 100 & 14.3 & 100 \\
\hline & 10 & 12.81 & 89.58 & 13.62 & 95.25 & 13.11 & 91.68 \\
\hline & 20 & 9.26 & 64.76 & 12.3 & 86.01 & 12.01 & 83.99 \\
\hline & 30 & 7.06 & 49.37 & 9.22 & 64.48 & 9.07 & 63.43 \\
\hline & 40 & 5.34 & 37.34 & 6.78 & 47.41 & 5.67 & 39.66 \\
\hline & 50 & 2.44 & 17.06 & 5.21 & 36.43 & 3.45 & 24.13 \\
\hline \multirow{6}{*}{28 Days } & 0 & 20.85 & 100 & 20.85 & 100 & 20.85 & 100 \\
\hline & 10 & 18.06 & 86.62 & 18.66 & 89.50 & 17.41 & 83.50 \\
\hline & 20 & 15.85 & 76.02 & 17.33 & 83.12 & 15.86 & 76.07 \\
\hline & 30 & 13.3 & 63.79 & 15.11 & 72.47 & 13.98 & 67.05 \\
\hline & 40 & 11.37 & 54.53 & 12.67 & 60.77 & 11.47 & 55.01 \\
\hline & 50 & 5.99 & 28.73 & 9.96 & 47.77 & 6.24 & 29.93 \\
\hline
\end{tabular}

TABLE 3. Strength Activity Index of PCS, PPS and PPKS.

index for the pozzolan blended concretes are is presented in Table 3. From Table 3 at 7 -day, the three pozzolans met the specification for the $10 \%$ replacement, and but at the $20 \%$ replacement level, two pozzolans (PPS \& PPKS) met the minimum permissible level of $75 \%$ of their control strength. At 28 days curing age, the maximum SAIs for $10 \%$ to $50 \%$ are $86.62 \%, 89.50 \%$ and $83.50 \%$ for $10 \%$ replacement level, $76.02 \%, 83.11 \%$ and $76.07 \%$ for $20 \%$ replacement level, $63.79 \%, 72.47 \%$ and $67.05 \%$ for $30 \%$ replacement level, $54.53 \%, 60.77 \%$ and $55.01 \%$ for $40 \%$ replacement level, $28.73 \%, 47.77 \%$ and $29.93 \%$ for $50 \%$ replacement level. This implies that up to $20 \%$ replacement could be adopted as an optimum replacement level of cement with pulverized coconut shell, periwinkle shell and/or palm kernel shell for normal concrete production.

\subsection{EFFECT OF PCS, PPS AND PKS ON TENSILE STRENGTH OF CONCRETE}

The experimental results of the tensile strength of the investigated pozzolan blended concretes are presented in figures $8 \mathrm{a}$ and $8 \mathrm{~b}$. The tensile strength increased significantly as the curing ages increased from 7 days to 28 days. Figure 8 shows the test results of the PCS, PPS and PPKS blended concretes varied from control $(0 \%)$ to the $50 \%$ replacement level at an interval of $10 \%$ for 7 - and 28- days of water curing. From these figures, it is observed that the use of these pozzolans as a cement replacement resulted in a decline in the tensile strength of the concretes. The increase in the replacement level of cement in the concrete matrix resulted to in an increase in the reduction of tensile strength to $19.08 \%, 25.77 \%, 44.79 \%, 48.47 \%$ and $67.49 \%$ for PCS, $16.33 \%, 18.84 \%, 37.27 \%, 42.57 \%$ and $45.93 \%$ for PPS, $21.93 \%, 25.72 \%, 41.96 \%, 48.01 \%$ and $58.90 \%$ for PPKS when compared with the control mix at 28 days. Also, it was observed that the tensile strength for the pozzolans blended concrete varies between $1 / 8$ to $1 / 12$ of their compressive strength.

\subsection{MATHEMATICAL MODEL TO PREDiCT COMPRESSIVE STRENGTH OF POZZOLANS BLENDED CONCRETE PROPERTIES}

Predictive models were developed using Bilinear Interpolation Method for two inputs and one output system; having the two inputs as being the curing age and percentage replacement for the different pozzolans. The mathematical models developed are presented below;

For the compressive strength of pulverized coconut shell;

$$
\begin{gathered}
f_{c u}=-2.558333359 \times 10^{-7} R^{5}- \\
-0.00001083332963 R^{4}+0.002996249948 R^{3}- \\
-0.00022837706 C^{3}+12.91000000+0.012408169 C^{2}- \\
-0.1152666679 R^{2}+2.275672175 \times 10^{-10} R^{5} C^{3}- \\
-1.222789117 \times 10^{-8} R^{5} C^{2}+1.525396828 \times 10^{-7} R^{5} C_{-} \\
-1.988176304 \times 10^{-8} R^{4} C^{3}+1.071003446 \times 10^{-6} R^{4} C^{2}- \\
-0.00001167758013 R^{4} C+4.02089414 \times 10^{-7} R^{3} C^{3}- \\
\quad-0.2134353783 \times 10^{-3} R^{3} C^{2}+ \\
+0.4369424621 \times 10^{-4} R^{3} C+ \\
+3.39731152 \times 10^{-6} R^{2} C^{3}-0.0002122023963 R^{2} C^{2}+ \\
+0.00899871059 R^{2} C-0.0000978781988 R C^{3}+ \\
+0.00574642857 R C^{2}-0.1369956349 R C+ \\
\quad+0.125476196 C+0.9554333322 R \quad(4)
\end{gathered}
$$

For the compressive strength of pulverized periwinkle shell;

$$
\begin{gathered}
f_{c u}=-8.749999850 \times 10^{-7} R^{5}+ \\
+0.0001254166631 R^{4}-0.006229166683 R^{3}- \\
-0.00022837706 C^{3}+12.91000000+0.012408169 C^{2}+
\end{gathered}
$$




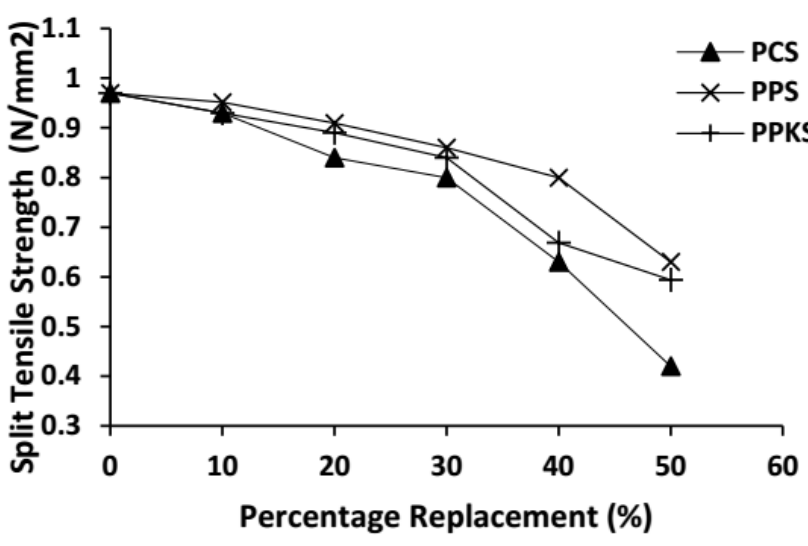

A. 7 days curing age

(A)

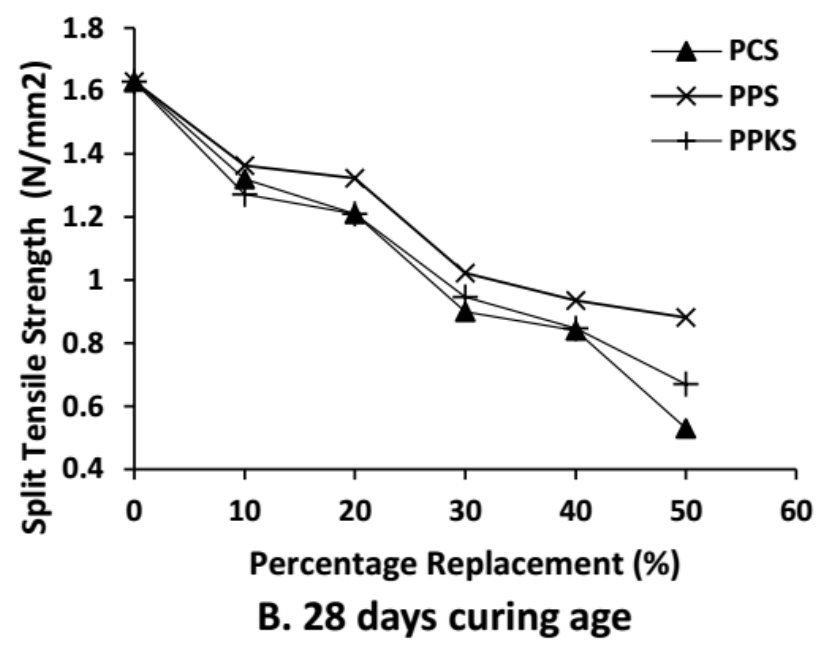

(B).

Figure 8. Split Tensile Strength of Pozzolans Blended Concrete at 7- and 28-days Curing ages.

$+0.1228083290 R^{2}-3.753644352 \times 10^{-10} R^{5} C^{3}+$ $+1.145408186 \times 10^{-8} R^{5} C^{2}-4.52381311 \times 10^{-9} R^{5} C+$ $+4.047214231 \times 10^{-8} R^{4} C^{3}-1.137329988 \times 10^{-6} R^{4} C^{2}-$ $-3.069443624 \times 10^{-6} R^{4} C-1.341715255 \times 10^{-6} R^{3} C^{3}+$ $+0.00003064200662 R^{3} C^{2}+0.0003516666700 R^{3} C+$ $+0.00001091877345 R^{2} C^{3}+0.0000203655832 R^{2} C^{2}-$$$
-0.01218710214 R^{2} C+0.0000971088407 R C^{3}-
$$$$
-0.007122618889 R C^{2}+0.1413428547 R C+
$$$$
+0.125476196 C-0.9488333240 R
$$

For the compressive strength of pulverized palm kernel shell;

$$
\begin{aligned}
f_{c u}= & -3.56250000 \times 10^{-6} R^{5}+ \\
+ & 0.0004691666657 R^{4}-0.02144708339 R^{3}- \\
- & 0.00022837706 C^{3}+12.91000000+ \\
+ & 0.012408169 C^{2}+0.3921833343 R^{2}+ \\
& +7.871720176 \times 10^{-10} R^{5} C^{3}- \\
& -4.452380980 \times 10^{-8} R^{5} C^{2}+
\end{aligned}
$$$$
+7.457142890 \times 10^{-7} R^{5} C-1.018788466 \times 10^{-7} R^{4} C^{3}+
$$$$
+5.758928567 \times 10^{-6} R^{4} C^{2}-0.00009674305549 R^{4} C+
$$$$
+4.616942050 \times 10^{-6} R^{3} C^{3}-
$$$$
-0.2604336751 \times 10^{-3} R^{3} C^{2}+
$$$$
+0.4369424621 \times 10^{-2} R^{3} C-
$$$$
-0.8636216480 \times 10^{-4} R^{2} C^{3}+
$$$$
+0.004841454123 R^{2} C^{2}-0.08025902824 R^{2} C+
$$$$
+0.0005877713022 R C^{3}-0.03239914980 R C^{2}+
$$$$
+0.5147194461 R C+0.125476196 C-
$$$$
-2.548666671 R
$$

Where: $R$ - Percentage Replacement Level and $C$ Curing Age.
Table 4 shows the comparison of the results of experimental findings and bilinear interpolation models. From the percentage difference calculated for each replacement level for all the pozzolans, it was observed that the values of the mathematical models are in good agreements with the experimental results.

The two-way statistical analysis of variance (ANOVA) without replication on the 7, 14, 21 and 28-day compressive strength results at $95 \%$ confidence level (that is $\infty=5$ ) is presented in table 5 . The percentage replacements level and curing age were considered as the source of variations of the compressive strength.

From Table 5 the p-values for the rows and columns of the PCS, PPS and PPKS are less than 0.05 and F is greater than F-crit, we reject the null hypothesis, and so at the $95 \%$ level of confidence we conclude that the curing age and the percentage replacement have a significant effect on the compressive strength of concrete.

\section{Conclusions}

From research carried out, the following conclusions can be made:

(1.) The quality of the PCS, PPS and PPKS materials were below the limits of Class $\mathrm{F}, \mathrm{C}$ and $\mathrm{N}$ pozzolanic materials according to ASTM C 618.

(2.) The addition of the PCS, PPS and PPKS to the cement paste matrix resulted in an increase in the setting. This indicates that the three pozzolans are good retarders, hence they can be used for a construction where an early setting of concrete is not required such as plastering of walls.

(3.) The workability of the pozzolans blended concrete decrease with an increase in the pozzolans replacement level. This resulted in stiff mixes. 


\begin{tabular}{ccccccccccc}
\hline $\begin{array}{c}\text { Curing } \\
\text { Age }\end{array}$ & $\begin{array}{c}\text { Per. } \\
\text { Rep. } \%)\end{array}$ & PCS & Model & Per. Diff. & PPS & Model & Per. Diff. & PPKS & Model & Per. Diff. \\
\hline \multirow{6}{*}{7 Days } & 0 & 14.3 & 14.300 & $-4.895 \mathrm{E}-07$ & 14.3 & 14.300 & $-4.9 \mathrm{E}-07$ & 14.3 & 14.300 & $-4.9 \mathrm{E}-07$ \\
& 10 & 12.81 & 12.810 & $-3.123 \mathrm{E}-07$ & 13.62 & 13.620 & $-5.9 \mathrm{E}-07$ & 13.11 & 13.110 & $-2.3 \mathrm{E}-07$ \\
& 20 & 9.26 & 9.259 & $3.24 \mathrm{E}-07$ & 12.3 & 12.300 & $-6.5 \mathrm{E}-07$ & 12.01 & 12.009 & $2.16 \mathrm{E}-06$ \\
& 30 & 7.06 & 7.059 & $1.261 \mathrm{E}-06$ & 9.22 & 9.220 & $-5.6 \mathrm{E}-07$ & 9.07 & 9.069 & $6.63 \mathrm{E}-06$ \\
& 50 & 5.34 & 5.339 & $5 \mathrm{E}-06$ & 6.78 & 6.779 & $5.32 \mathrm{E}-06$ & 5.67 & 5.669 & $6.48 \mathrm{E}-05$ \\
& 50 & 2.44 & 2.439 & $1.643 \mathrm{E}-05$ & 5.21 & 5.209 & $4.07 \mathrm{E}-05$ & 3.45 & 3.449 & 0.000137 \\
\hline \multirow{6}{*}{28 Days } & 0 & 20.85 & 20.850 & $-3.453 \mathrm{E}-06$ & 20.85 & 20.850 & $-3.5 \mathrm{E}-06$ & 20.85 & 20.850 & $-3.5 \mathrm{E}-06$ \\
& 10 & 18.06 & 18.060 & $-3.433 \mathrm{E}-06$ & 18.66 & 18.660 & $-4.1 \mathrm{E}-06$ & 17.41 & 17.410 & $-4.6 \mathrm{E}-06$ \\
& 20 & 15.85 & 15.850 & $-2.082 \mathrm{E}-06$ & 17.33 & 17.3300 & $-4.7 \mathrm{E}-06$ & 15.86 & 15.860 & $-1.3 \mathrm{E}-06$ \\
& 13.3 & 13.299 & $3.158 \mathrm{E}-06$ & 15.11 & 15.110 & $-6.3 \mathrm{E}-06$ & 13.98 & 13.980 & $-2 \mathrm{E}-05$ \\
& 50 & 11.37 & 11.369 & $1.706 \mathrm{E}-05$ & 12.67 & 12.670 & $-8.7 \mathrm{E}-07$ & 11.47 & 11.469 & $8.55 \mathrm{E}-05$ \\
& 5.99 & 5.989 & $8.681 \mathrm{E}-05$ & 9.96 & 9.959 & $4.69 \mathrm{E}-05$ & 6.24 & 6.240 & $-2.7 \mathrm{E}-05$ \\
\hline
\end{tabular}

TABLE 4. Validation of Developed Model for Compressive Strength (N/mm2) of Pozzolans (PCS, PPS and PPKS) Blended Concretes.

\begin{tabular}{lcccccc}
\hline \multicolumn{7}{c}{ ANOVA FOR PCS } \\
\hline Source of Variation & SS & df & MS & F & P-value & F crit \\
\hline Rows & 459.2312 & 5 & 91.84623 & 305.9878 & $1.54 \mathrm{E}-14$ & 2.901295 \\
Columns & 109.5279 & 3 & 36.50929 & 121.6315 & $9.47 \mathrm{E}-11$ & 3.287382 \\
Error & 4.502446 & 15 & 0.300163 & & & \\
Total & & & & & & \\
& 573.2615 & 23 & & & & \\
\end{tabular}

\begin{tabular}{lcccccc}
\hline \multicolumn{7}{c}{ ANOVA FOR PPS } \\
\hline Source of Variation & SS & df & MS & F & P-value & F crit \\
\hline Rows & 286.7838 & 5 & 57.35675 & 339.8477 & $7.06 \mathrm{E}-15$ & 2.901295 \\
Columns & 103.4237 & 3 & 34.47458 & 204.2673 & $2.2 \mathrm{E}-12$ & 3.287382 \\
Error & 2.531579 & 15 & 0.168772 & & & \\
Total & & & & & & \\
& 392.7391 & 23 & & & & \\
\end{tabular}

\begin{tabular}{lcccccc}
\hline \multicolumn{7}{c}{ ANOVA FOR PPKS } \\
\hline Source of Variation & SS & df & MS & F & P-value & F crit \\
\hline Rows & 431.5447 & 5 & 86.30893 & 235.6973 & $1.06 \mathrm{E}-13$ & 2.901295 \\
Columns & 72.07297 & 3 & 24.02432 & 65.60696 & $7.46 \mathrm{E}-09$ & 3.287382 \\
Error & 5.492783 & 15 & 0.366186 & & & \\
Total & & & & & & \\
\hline
\end{tabular}

TABle 5. Results of Two-way Analysis of Variance for Compressive Strength (N/mm²) of Pozzolans (PCS, PPS and PPKS) Blended Concretes. 
(4.) The density of pulverized coconut shell (PCS) blended concrete decreased as the replacement level increased while the densities of pulverized periwinkle shell (PPS) blended concrete and pulverized palm kernel shell (PPKS) blended concrete increased for values of up to $30 \%$ replacement level and further replacement levels led to a decrease.

(5.) The compressive strength and tensile strength declined as the percentage replacement increased from $0 \%$ to $50 \%$ at $10 \%$ intervals for the three pozzolans. The values of compressive strength for the three pozzolans are above $17 \mathrm{~N} / \mathrm{mm}^{2}$ at the $10 \%$ replacement level; an indication that the PCS, PPS and PPKS at the $10 \%$ replacement level are suitable for the production of pozzolans blended concrete for structural works using a water-binder ratio of 0.6 .

(6.) At 28 days curing age, the strength activity index for the pozzolans blended concretes was more than $75 \%$ of the strength of normal concrete at the $20 \%$ replacement level. The tensile strength for the pozzolans blended concretes varied between $1 / 8$ to $1 / 12$ of their compressive strength.

(7.) The models developed using the bilinear interpolation method for the compressive strengths of the PCS, PPS, and PPKS blended concrete are in a good agreement with the experimental results. The statistical analysis of the variance showed that the replacement level of the PCS, PPS, and PPKS contents and curing age have effect on the compressive strength of concrete.

\section{ACKNOWLEDGEMENTS}

The authors would like to express their gratitude to University of Lagos for providing the enabling environment to conduct this research work.

\section{REFERENCES}

[1] B. C. McLellan, R. P. Williams, J. Lay, et al. Costs and carbon emissions for geopolymer pastes in comparison to ordinary portland cement. Journal of Cleaner Production 19(9):1080 - 1090, 2011. DOI:10.1016/j.jclepro.2011.02.010

[2] R. M. Andrew. Global $\mathrm{CO}_{2}$ emissions from cement production, 1928-2017. Earth System Science Data 10(4):2213-2239, 2018. DOI:10.5194/essd-10-2213-2018.

[3] E. Ikponmwosa, S. Ehikhuenmen. The effect of ceramic waste as coarse aggregate on stregth properties of concrete. Nigerian Journal of Technology 36(3):691 696, 2017. DOI:10.4314/njt.v36i3.5

[4] ASTM C618-08 - Standard Specification for Coal fly ash and raw or Calcined Natural Pozzolan for use in concrete. Standard, American Society for Testing and Materials, West Conshohocken, 2008.

[5] S. Donatello, M. Tyrer, C. Cheeseman. Comparison of test methods to assess pozzolanic activity. Cement and Concrete Composites 32(2):121 - 127, 2010.

DOI:10.1016/j.cemconcomp.2009.10.008
[6] G. L. Golewski. The influence of microcrack width on the mechanical parameters in concrete with the addition of fly ash: Consideration of technological and ecological benefits. Construction and Building Materials 197:849 861, 2019. DOI:10.1016/j.conbuildmat.2018.08.157.

[7] G. L. Golewski. Determination of fracture toughness in concretes containing siliceous fly ash during mode III loading. Structural Engineering and Mechanics 62(1):1-9.

[8] G. L. Golewski. Effect of fly ash addition on the fracture toughness of plain concrete at third model of fracture. Journal of Civil Engineering and Management 23(5):613 - 620, 2017. DOI:10.3846/13923730.2016.1217923.

[9] F. Falade, E. Ikponmwosa, C. Fapohunda. Potential of pulverized bone as a pozzolanic material. International Journal of Scientific \& Engineering Research 3(7):1 - 6, 2012.

[10] E. Ikponmwosa, M. Salau, S. Mustapha. Strength characteristics of concrete beams with cement partially replaced by uncalcined soldier-ant mound clay. In Second International Conference on Advances in Engineering and Technology Strength, pp. 402 - 408. 2011.

[11] E. Ikponmwosa, C. Fapohunda, S. Ehikhuenmen. Suitability of polyvinyl waste powder as partial replacement for cement in concrete production. Nigerian Journal of Technology 33(4):504 - 511, 2014. DOI:10.4314/njt.v33i4.11

[12] M. V. S. Reddy, K. Ashalatha, M. Madhuri, P. Sumalatha. Utilization of sugarcane bagasse ash (SCBA) in concrete by partial replacement of cement. IOSR Journal of Mechanical and Civil Engineering 12(6):12 - 16, 2015. DOI:10.4314/njt.v33i4.11.

[13] BS 8110-1:1997 - Structural use of concrete. Standard, British Standards Institution, London, 2004.

[14] C. Marthong. Sawdust ash (SDA) as partial replacement of cement. International Journal of Engineering Research and Applications 2(4):1980 1985, 2012.

[15] J. Utsev, K. Taku. Coconut shell ash as partial replacement of ordinary portland cement in concrete production. International journal of scientific $\mathbb{E}$ technology research 1(8):86 - 89, 2012.

[16] A. Umoh, O. O. Femi. Comparative evaluation of concrete properties with varying proportions of periwinkle shell and bamboo leaf ashes replacing cement. Ethiopian Journal of Environmental Studies and Management 6(5):570 - 580, 2013. DOI:10.4314/ejesm.v6i5.15

[17] U. Offiong, G. Akpan. Assessment of physico-chemical properties of periwinkle shell ash as partial replacement for cement in concrete. International journal of scientific engineering and science 1(7):33 - 36, 2017.

[18] ASTM C618-12a - Standard Specification for Coal Fly Ash and Raw or Calcined Natural Pozzolan for Use in Concrete. Standard, American Society for Testing and Materials, West Conshohocken, 2012.

[19] I. Attah, R. Etim, D. Ekpo. Behaviour of periwinkle shell ash blended cement concrete in sulphuric acid environment. Nigerian Journal of Technology 37(2):315 - 321, 2018. DOI:10.4314/njt.v37i2.5. 
[20] I. Abdullahi, S. G. Sara. Assessment of periwinkle shells ash as composite materials for particle board production. In International Conference on African Development Issues: Materials Teclmology Track Assessment, pp. 158 - 163. 2015.

[21] F. A. Olutoge, O. M. Okeyinka, O. S. Olaniyan, I. Oyo. Assessment of the suitability of periwinkle shell ash (PSA) as partial replacement for ordinary portland cement (OPC) in concrete 10(3):428 - 434, 2012.

[22] F. A. Olutoge, H. A. Quadri, O. S. Olafusi. Investigation of the strength properties of palm kernel shell ash concrete. Engineering, Technology $\&$ Applied Science Research 2(6):315 - 319, 2012

[23] J. Oti, J. Kinuthia, R. Robinson, P. Davies. The use of palm kernel shell and ash for concrete production. World Academy of Science, Engineering and Technology International Journal of Civil, Structural, Construction and Architectural Engineering 9(3):210 - 217, 2015.

[24] H. Hardjasaputra, I. Fernando, J. Indrajaya, et al. The effect of using palm kernel shell ash and rice husk ash on geopolymer concrete. MATEC Web of Conferences 251, 2018. DOI:10.1051/matecconf/201825101044

[25] A. S. Leman, S. Shahidan, M. S. Senin, N. I. R. R. Hannan. A preliminary study on chemical and physical properties of coconut shell powder as a filler in concrete. IOP Conference Series: Materials Science and Engineering 160(1), 2016. DOI: $10.1088 / 1757-899 x / 160 / 1 / 012059$

[26] O. J. Oyedepo, L. M. Olanitori, S. P. Akande. Performance of coconut shell ash and palm kernel shell ash as partial replacement for cement in concrete. Journal of Building Materials and Structures 2(1):18 24, 2015. DOI:10.5281/zenodo.241986.

[27] W. Akhionbare. A comparative evaluation of the application of agrowaste as construction material. International Journal of Science and Nature 4(1):141 144, 2013.

[28] ASTM C150/C150M-18 - Standard Specification for Portland Cement. Standard, American Society for Testing and Materials, West Conshohocken, 2018.

[29] BS 12:1996 - Specification for Portland cement. Standard, British Standards Institution, London, 1996.

[30] BS EN 197-1:2011 - Cement. Composition, specifications and conformity criteria for common cements. Standard, British Standards Institution, London, 2011.
[31] BS 882:1992 - Specification for aggregates from natural sources for concrete. Standard, British Standards Institution, London, 1992.

[32] BS 3148:1980 - Methods of test for water for making concrete (including notes on the suitability of the water). Standard, British Standards Institution, London, 1980.

[33] BS EN 12390-3:2009 - Testing hardened concrete. Compressive strength of test specimens. Standard, British Standards Institution, London, 2009.

[34] BS EN 12390-6:2009 - Testing hardened concrete. Tensile splitting strength of test specimens. Standard, British Standards Institution, London, 2010.

[35] ASTM C496-96 - Standard Test Method for Splitting Tensile Strength of Cylindrical Concrete Specimens. Standard, American Society for Testing and Materials, West Conshohocken, 1996.

[36] ASTM C618-12a - Standard Specification for Coal Fly Ash and Raw or Calcined Natural Pozzolan for Use in Concrete. Standard, American Society for Testing and Materials, West Conshohocken, 2012.

[37] ASTM D2487-11 - Standard Practice for Classification of Soils for Engineering Purposes (Unified Soil Classification System). Standard, American Society for Testing and Materials, West Conshohocken, 2011.

[38] ASTM D3282-09 - Standard Practice for Classification of Soils and Soil-Aggregate Mixtures for Highway Construction Purposes. Standard, American Society for Testing and Materials, West Conshohocken, 2009.

[39] ASTM C33/C33M-18 - Standard Specification for Concrete Aggregates. Standard, American Society for Testing and Materials, West Conshohocken, 2018.

[40] BS 812-110:1990 - Testing Aggregates. Method for determination of aggregate crushing value. Standard, British Standards Institution, London, 1990.

[41] BS EN 196-3:2016, Methods of testing cement. Determination of setting time and soundness. Standard, British Standards Institution, London, 2016. 